\title{
Genetic diversity of phenol hydroxylase-encoding genes among wastewater sludge bacteria
}

\author{
WATUMESA AGUSTINA TAN", FEDHO KUSUMA \\ Faculty of Biotechnology, Universitas Katolik Indonesia Atma Jaya. Jl. Raya Cisauk-Lapan No. 10, Tangerang 15345, Banten, Indonesia. \\ Tel. +62-21-80827200, `email: tan.watumesa@atmajaya.ac.id
}

Manuscript received: 3 August 2021. Revision accepted: 22 September 2021.

\begin{abstract}
Tan WA, Kusuma F. 2021. Genetic diversity of phenol hydroxylase-encoding genes among wastewater sludge bacteria. Biodiversitas 22: 4291-4297. Phenol is a toxic aromatic compound that is used in various industries. In this study, we explore the molecular diversity of bacterial genes that encode for phenol hydroxylase, a key enzyme for phenol degradation, within sludge samples collected from the aeration and microbial recovery tank of an automotive wastewater treatment system. Partial phenol hydroxylaseencoding gene (600 bp) was amplified from the total DNA of each tank using a degenerate primer pair and cloned to construct a gene library. A total of 37 and 38 clones were obtained from the aeration and microbial recovery tank, respectively. The clones were sequenced and compared to GenBank database using BLASTX, followed by neighbor joining-based phylogenetic analysis using MEGA7. A majority of the clones recovered from both tanks belonged to Betaproteobacteria, which have been reported as phenol degraders with various metabolic activities and lifestyles. The clones are grouped into eight clusters. Six clusters were present in both the aeration and microbial recovery tank, and one unique cluster was identified in each tank. This indicated that diverse microbial communities play a role in phenol-containing wastewater treatment. They may have changed throughout the process as the surrounding chemical compositions differed and a variety of metabolic roles surfaced.
\end{abstract}

Keywords: Bioremediation, genetic diversity, phenol hydroxylase, wastewater sludge

\section{INTRODUCTION}

Phenol is an aromatic compound that consists of a benzene ring and a hydroxyl group as its substituent. The compound is used in various industrial processes such as the petrochemical, pharmaceutical, paint and resin manufacture. Phenol and its derivatives are present in these industrial effluents at high concentrations (Naguib and Badawi 2020). The processing and disposal of wastewater contaminated with these compounds are of concern because of their stable and recalcitrant nature. Previous reports have indicated that prolonged exposure to phenol may induce apoptosis of the red blood cells and cause various health impacts to the skin, kidney, lungs, liver and nervous system (Zhong et al. 2012; Michałowicz et al. 2018). Furthermore, phenol exposure was reported to affect hormonal regulation during pregnancy, which is associated to adverse birth outcomes (Aker et al. 2019).

Due to the toxic nature of phenol and its derivatives, the compounds are considered priority pollutants. This led to an emerging need of phenolic waste treatments for a sustainable environment. The conventional physicochemical treatments for phenol removal from wastewater exhibit high efficiencies but they require high energy costs. On the other hand, biological treatments using microorganisms offer a much more ecologically friendly solution. Many bacterial strains capable of assimilating phenol in its growth from environmental samples have been isolated and identified (Ke et al. 2018; Panigrahy et al. 2020; Barik et al. 2021).
Aerobic phenol biodegradation is initiated by phenol hydroxylase (also known as phenol-2-monooxygenase), a ring hydroxylating enzyme that incorporates an atom of oxygen into the substrate to produce catechol, a common intermediate for aerobic aromatic degradation. Catechol is then cleaved by catechol dioxygenase either via the metaor ortho- pathway. This is followed by several steps of degradation that feed into the central metabolism (Nešvera et al. 2015). Two types of phenol hydroxylase have been discovered, the single-component and multi-component enzymes, with the latter being dominant in the environment (Setlhare et al. 2020; Chenprakhon et al. 2020). Previous research has shown that consensus amino acid sequence in the catalytic domain of the multicomponent phenol hydroxylase may be used as a molecular marker in screening for phenol-degrading bacteria (Harzallah et al. 2017; Chenprakhon et al. 2020).

While many research have provided information about phenol degradation mechanisms in microorganisms, less is known regarding the bacterial genetic diversity of phenol hydroxylases within a specific environment, particularly the wastewater sludge. This study aims to investigate the genetic diversity of bacterial phenol hydroxylases within wastewater sludge samples. Such information may give insight into potential phenol-degrading bacteria and novel functional genes. 


\section{MATERIALS AND METHODS}

\section{Sampling and DNA extraction}

Sludge samples were collected from the aeration and microbe recycle tank of an automotive industry wastewater treatment plant in Jakarta, Indonesia (Figure 1). In the system, wastewater is channeled into the aeration tank and into a sedimentation tank where the sludge will settle at the bottom. A portion of the sludge is then transferred into the microbial recovery tank to allow for regrowth of microbe and later siphoned back into the aeration tank. Genomic DNA was extracted from the samples using ZymoBIOMICS ${ }^{\circledR}$ DNA Kit (Zymo Research). DNA concentration and purity were quantified using NanoDrop ${ }^{\text {TM }} 2000$ c (Themo Fisher Scientific).

\section{Polymerase chain reaction (PCR)}

Partial phenol hydroxylase-encoding gene of approximately $600 \mathrm{bp}$ in size was amplified using the primer pairs, pheUf (5'-CCAGGSBGARAARGAGARGAARC3') and pheUr (5'-CGGWARCCGCGCCAGAACCA-3') according to Futamata et al. (2001). The $50-\mu \mathrm{L}$ reaction mixture contained GoTaq ${ }^{\circledR}$ Green Master Mix (Promega), 10 pmol of each primer, $100 \mathrm{ng}$ of sample DNA as template, and nuclease-free water. PCR reactions were performed in Applied Biosystems ${ }^{\mathrm{TM}}$ Thermal Cycler with following conditions: 10 minutes of pre-denaturation at $94^{\circ} \mathrm{C}$, and 30 cycles consisting of 1 minute at $94^{\circ} \mathrm{C}, 1$ minute at $58^{\circ} \mathrm{C}$, and 1 minute at $72^{\circ} \mathrm{C}$, and 10 minutes of extension at $72^{\circ} \mathrm{C}$. PCR products were run on $1 \% \mathrm{w} / \mathrm{v}$ agarose gel in TAE buffer ( $\mathrm{pH} 8.3$ ) with $1 \mathrm{~kb}$ DNA Ladder (GENESTA ${ }^{\mathrm{TM}}$ ) as marker, then further visualized using Infinity CX5 (Vilber Lourmat ${ }^{\mathrm{TM}}$ ). The 600-bp target band was excised from the gel and purified using QIAquick Gel Extraction Kit (QIAGEN).

\section{Library construction}

The purified DNA band from each sample was ligated to pGEM ${ }^{\circledR}-\mathrm{T}$ easy vector (Promega) and transformed to Escherichia coli DH5 $\alpha$. White bacterial colonies suspected to carry recombinant plasmid were further purified on Luria Agar supplemented with $100 \mu \mathrm{g} \mathrm{mL} \mathrm{m}^{-1}$ ampicillin. Colony PCR was conducted to amplify cloned gene from the colonies using the M13f (5'-GTAAAACGACGGC CAGT-3') and M13r (5'-CAGGAAACAGCTATGAC-3') primer pair, which flanked the vector cloning site as described by the manufacturer. PCR reactions were as follow: 5 minutes of pre-denaturation at $95^{\circ} \mathrm{C}$, and 30 cycles consisting of 30 seconds at $95^{\circ} \mathrm{C}, 30$ seconds at $50^{\circ} \mathrm{C}$, and 1 minute at $72^{\circ} \mathrm{C}$, and 5 minutes of extension at $72^{\circ} \mathrm{C}$.

\section{Phylogenetic analysis}

Amplified cloned genes were sent to Macrogen, South Korea for sequencing. Obtained sequences were compared to the GenBank database using BLASTX (ncbi.nlm.nih.gov). Partial phenol hydroxylase sequences of significant hits and known phenol-degrading bacteria were used as reference sequences. Clones and reference sequences were aligned using ClustalW algorithm prior to Neighbor-joining phylogenetic tree construction using the MEGA7 software (Kumar et al. 2016). Shannon's diversity index was calculated for each tank using the following formula: $H=-\sum\left[\left(p_{i}\right) * \ln \left(p_{i}\right)\right]$, while evenness was expressed as $H / \ln S$ (Shannon and Weaver 1963). The value of $p_{i}$ represents the proportion of the number of clones in a tank that showed similarity to a particular hit based on BLASTX to the number of total clones recovered from said tank, and $\mathrm{S}$ is the total number of different hits within a tank.

\section{RESULTS AND DISCUSSION}

\section{PCR and library construction}

Partial phenol hydroxylase genes were amplified using the pheUf and pheUr universal primer pair designed by Futamata et al. (2001), which target the approximately 600bp region that encodes for a domain responsible for transition metal ion-binding within the enzyme. Agarose gel visualization revealed multiple bands in the PCR products, with the targeted 600-bp band being the brightest amplified band (

Figure 2). The presence of other non-specific bands was mainly due to the use of degenerate primers as it contained alternate bases at several positions in the primers. The 600bp DNA fragments that represent partial phenol hydroxylase genes (Futamata et al. 2001) were further purified from the gel and cloned in pGEM®-T easy vector. A total of 37 and 38 clones were obtained from the aeration and microbial recovery tank, respectively.

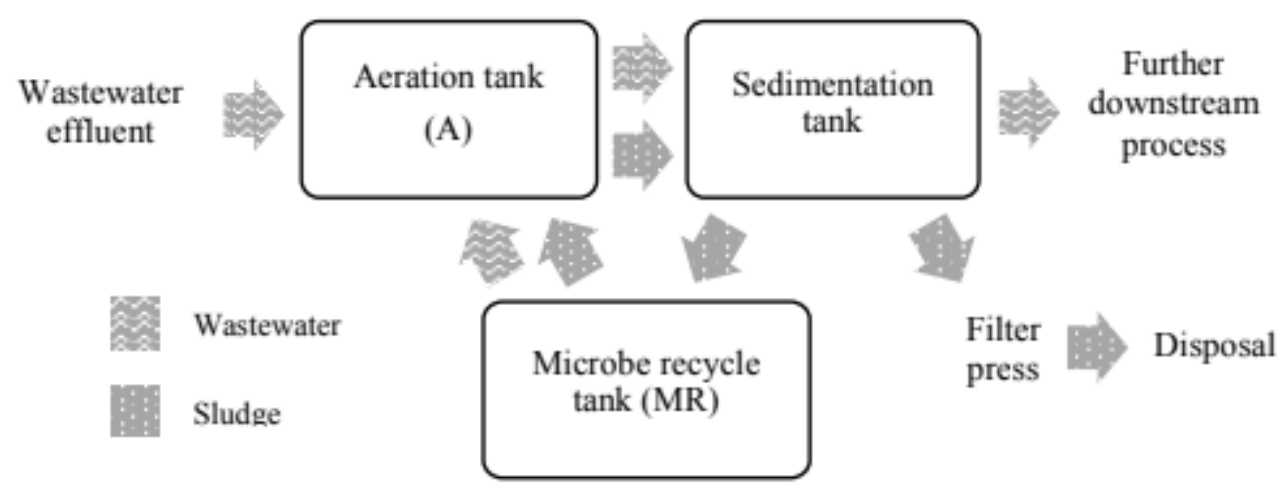

Figure 1. Wastewater treatment system used in this study. Samples were collected from the aeration (A) and microbe recycle tank (MR) 


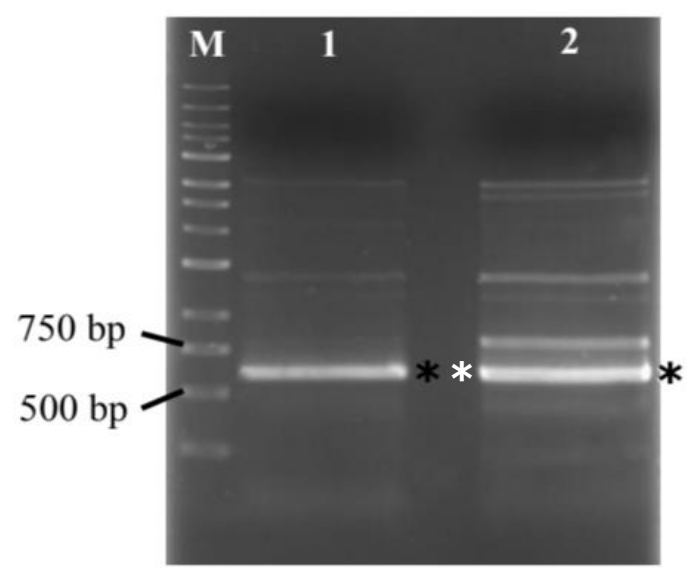

Figure 2. Amplified partial phenol hydroxylase-encoding genes. Lane M, GENESTA ${ }^{\mathrm{TM}} 1 \mathrm{~kb}$ DNA Ladder; lane 1 , wastewater sludge DNA from aeration tank; lane 2, wastewater sludge DNA from microbial recycle tank; asterisks $\left(^{*}\right)$ indicate 600 -bp bands encoding for phenol hydroxylase as described by Futamata et al. (2001).

BLASTX analysis showed that the clones shared relatively high similarities (90-97\%) with all bacterial hits, which include a group of phenol hydroxylases, YHSdomain containing protein, and related monooxygenases (Table 1). Multicomponent phenol hydroxylases belong to the soluble diiron monooxygenase group (Chenprakon et al. 2020). These group of enzymes are known to recognize a wide variety of substrates aside from phenol, including amino-, halogen-, hydroxyl-, or methyl-substituted phenols (Setlhare et al. 2020). Previous research showed that the YHS-domain, a small cytosolic protein domain consisting of 50 amino acids names after three conserved amino acid residues (tyrosine, histidine and serine), was also be found in some bacterial monooxygenases (Linder 2015). The YHS domain binds to transition metal ion, such as copper ion in ATPases, for molecular oxygen activation, and it is also suggested to play a role in incorporating iron to the oxygenase complex (Linder 2015; Petkevičius et al. 2021).

\section{Phylogenetic analysis}

In the phylogenetic tree, the clones were dispersed into eight clusters, revealing that both tanks have different microbial compositions (Figure 3). While cluster II-VII were identified in both the aeration and microbial recovery tanks, cluster I was uniquely detected in the aeration tank and cluster VIII was only found in the microbial recovery tank. Most of the clones (90\%) were related to Betaproteobacteria and a small group of clones was related to Alphaproteobacteria. Uniquely, Alphaproteobacteria was only identified in the aeration tank. The Shannon-Weiner indices further suggested that the microbial community in aeration tank was more diverse and evenly distributed than that in the microbe recycle tank (Error! Reference source not found.2).

Table 1. Protein hits and source organism from comparative analysis between cloned fragments and database using BLASTX

\begin{tabular}{|c|c|c|c|c|c|c|}
\hline \multicolumn{3}{|c|}{ Hit } & \multirow[t]{2}{*}{$\begin{array}{c}\text { Habitat/ Sample } \\
\text { source }\end{array}$} & \multicolumn{2}{|c|}{$\begin{array}{l}\text { Number of } \\
\text { clone }(\mathbf{s}) *\end{array}$} & \multirow[t]{2}{*}{$\begin{array}{c}\text { Identity } \\
\text { range }(\%)\end{array}$} \\
\hline Protein & Organism & Accession Number & & $\mathbf{A}$ & MR & \\
\hline \multirow{5}{*}{$\begin{array}{l}\text { YHS domain- } \\
\text { containing } \\
\text { protein }\end{array}$} & Methylibium sp. Root 1272 & WP_056326060.1 & Rhizosphere & 17 & 5 & $95-97$ \\
\hline & $\begin{array}{l}\text { Methylibium petroleiphilum } \\
\text { PM1 }\end{array}$ & WP_011829875.1 & $\begin{array}{l}\text { Biofilter of oil refinery } \\
\text { waste }\end{array}$ & 5 & & 96 \\
\hline & Methylibium sp. T29-B & EWS57398.1 & $\begin{array}{l}\text { Gasoline- } \\
\text { contaminated } \\
\text { groundwater }\end{array}$ & & 1 & 95 \\
\hline & Zavarzinia sp. HR-AS & WP_109908169.1 & Freshwater & 5 & & $97-98$ \\
\hline & Azoarcus toluclasticus MF63 & WP_018989553.1 & $\begin{array}{l}\text { Shallow aquifer } \\
\text { sediment }\end{array}$ & 2 & & 92 \\
\hline $\begin{array}{l}\text { Putative benzene } \\
\text { monooxygenase } \\
\text { large subunit }\end{array}$ & $\begin{array}{l}\text { Alicycliphilus denitrificans } \\
\mathrm{BC}\end{array}$ & ABQ88309.1 & $\begin{array}{l}\text { Enriched culture with } \\
\text { mixed wastewater and } \\
\text { soil }\end{array}$ & & 1 & 97 \\
\hline $\begin{array}{l}\text { Phenol-2- } \\
\text { monooxygenase }\end{array}$ & Rubrivivax sp. SCN 70-15 & ODV04934.1 & $\begin{array}{l}\text { Thiocyanate } \\
\text { bioreactor with mixed } \\
\text { wastewater sludge }\end{array}$ & 6 & 5 & $94-96$ \\
\hline $\begin{array}{l}\text { Largest subunit } \\
\text { of }\end{array}$ & $\begin{array}{l}\text { Uncultured bacterium clone } \\
322-\mathrm{T}\end{array}$ & BAF40989.1 & $\begin{array}{l}\text { Sewage sludge } \\
\text { compost }\end{array}$ & & 2 & 96 \\
\hline $\begin{array}{l}\text { multicomponent } \\
\text { phenol } \\
\text { hydroxylase }\end{array}$ & $\begin{array}{l}\text { Uncultured bacterium clone } \\
373-\mathrm{N}\end{array}$ & BAF41040.1 & $\begin{array}{l}\text { Sewage sludge } \\
\text { compost }\end{array}$ & & 1 & 97 \\
\hline \multirow[t]{3}{*}{$\begin{array}{l}\text { Soluble diiron } \\
\text { monooxygenase }\end{array}$} & $\begin{array}{l}\text { Uncultured bacterium clone } \\
\text { P85-86_Cl.2_HRB2-7m-2009 }\end{array}$ & CCO97067.1 & Soil & & 23 & $91-95$ \\
\hline & $\begin{array}{l}\text { Uncultured bacterium clone } \\
\text { P85-86_Cl.8_HRB0-5m-2008 }\end{array}$ & CCO97076.1 & Soil & 2 & & 90 \\
\hline & & & Total & 37 & 38 & \\
\hline
\end{tabular}

Note: *Represent total clones recovered from the aeration (A) and microbe recovery (MR) tank that showed similarity to relevant proteins 
Table 2. Shannon's diversity index and evenness of clones recovered from each tank

\begin{tabular}{lcc}
\hline \multirow{2}{*}{ Tank } & \multicolumn{2}{c}{ Diversity } \\
\cline { 2 - 3 } & Shannon index $(\boldsymbol{H})$ & Evenness \\
\hline Aeration & 1.51 & 0.84 \\
Microbial recycle & 1.06 & 0.66 \\
\hline
\end{tabular}

Figure 3 showed that both tanks have different consortia of microbes. Correspondingly, the diversity and evenness were also different (Table 1). In this study, sludge samples were collected from an aerobic activated sludge system. Activated sludge has been used to detoxify waste containing a mixture of phenol and other aromatic hydrocarbons, in which degradation of these compounds occurs during exposure to oxygen (Hussain et al. 2015; Sam et al. 2021). Therefore, phenol and other nutrient bioavailability in the aeration tank would be higher than in the microbial recycle tank. These substrates would be depleted due to microbial activities in the aeration tank, which would then provide the opportunity of certain bacteria that are capable of using remaining phenol and other unused compounds to grow in the microbial recovery tank. In addition, various levels of tolerance to phenol have been reported in different bacteria and mixed cultures (Bera et al. 2017; Viggor et al. 2020). Such difference in response to varying phenol concentrations will allow for growth of bacteria with diverse capability of phenol catabolism in both tanks. Some bacteria may be unable to withstand higher phenol concentrations during the early aeration phase of wastewater treatment yet thrive in lower phenol concentrations, which explains the presence of Cluster VIII that is unique to and dominant in the microbial recycle tank (Figure 3).

The phenol hydroxylase-encoding genes recovered in this study represent a multitude of bacteria with various lifestyles. A total of $38 \%$ of the clones were identified as Methylibium (Table 1). To date, M. petroleiphilum PM1 is the only member of the genus that has been identified up to the species level. The bacterium was originally discovered from a compost-filled biofilter in Los Angeles, California as a degrader of the fuel oxygenate methyl-tert-butyl-ether (MTBE) degrader (Kane et al. 2007). Whole genome sequence analysis showed that the $M$. petroleiphilum PM1 carry a set of genes for complete phenol degradation (Kane et al. 2007) yet the bacterium, alongside Methylibium in general, are not typically studied for their phenol catabolism ability. However, it should be noted that MTBE often is present with various components of gasoline, such as the monoaromatic compounds benzene, toluene, ethylbenzene and xylene (BTEX) as well as phenol (Chen et al. 2012; Stefanakis 2020), all of which are likely to cooccur in the automotive industry wastewater.

A smaller group of clones (16\%) were closely related to the genus Rubrivivax, the purple non sulfur bacteria which are generally found in wastewater sludge due to their ability to utilize a wide range of carbon sources (Nagashima et al. 2012; Mekala et al. 2018). Two of the most well-studied species belonging to Rubrivivax, namely
$R$. benzoatilyticus JA2 and $R$. gelatinosus 144, showed preference to photoheterotrophic lifestyle, despite that they are also known to survive under aerobic and fermentative growth conditions (Nagashima et al. 2012; Mekala et al. 2018). Similarly, a new strain isolated from a freshwater pond was recently proposed as $R$. albus (Sheu et al. 2020). Despite that there has yet been any direct evidence for growth on phenol, $R$. benzoatilyticus JA2 is known to degrade aromatic hydrocarbons (Mohammed et al. 2020).

Two clones (A003 and A023) were related to Azoarcus toluclasticus MF63, and one clone (MR004) was associated to Alicycliphilus denitrificans BC. Based on polyphasic analyses, A. toluclasticus MF63 has been reclassified as Aromatoleum toluclasticum (Rabus et al. 2019). The bacterium is capable of using phenol and toluene under denitrifying conditions (Song et al. 1999). The benzene monooxygenase of A. denitrificans MF63 can also recognize and catabolize phenol in either aerobic condition or using chlorate as an electron acceptor (Weelink et al. 2008). Such catabolism preference may vary among strains and substrates, as demonstrated through the whole genome comparison of A. denitrificans BC and K601 (Oosterkamp et al. 2013). While strain BC hydroxylates benzene with chlorate as an electron acceptor, the cyclohexanoldegrading denitrifying strain K601T is unable to use chlorate as an electron acceptor (Oosterkamp et al. 2013).

Apart from Betaproteobacteria, five clones were related to Zavarzinia, a carboxidotrophic Alphaproteobacteria that was recently reported as the main benzene degraders in oil sands process-affected water (Rochman et al. 2017). Zavarzinia can grow chemolithoautotrophically using carbon monoxide as a sole carbon and energy source under aerobic or denitrifying condition (Lee et al. 2019).

The result of this study demonstrated the eminent role of Betaproteobacteria in aromatic biodegradation, in which a majority of the clones recovered from both the aerial and microbial recycle tanks belong to this class. A study by Chen et al. (2017) showed that Proteobacteria dominated the wastewater sludge bacterial community and their relative abundance increased to around $80 \%$ of the total population when the sludge was adapted to $350 \mathrm{mg} / \mathrm{L}$ phenol, despite that further classification of the phylum was not described in detail. Silva et al. (2012) also reported that several genus belonging to Betaproteobacteria, including Diaphorobacter, Thauera, and Comamonas, were found in abundance in petroleum wastewater refineries enriched with phenol. Furthermore, a majority of genes for phenol degradation detected in the habitat also belong to Betaproteobacteria (Silva et al. 2013). Members of this bacterial class are known to be highly mobile and adaptable (Tan and Parales 2019). These traits ultimately may have contributed to its versatility in metabolism, which could also be seen from the various metabolic characteristics known for organisms showing similarity with the clones recovered in this study. Despite their lesserknown status as phenol or other aromatic degraders compared to the more well-known Gammaproteobacteria such as the fast-growing Pseudomonas spp., members of Betaproteobacteria may have a competitive advantage in a complex real-living environment. 


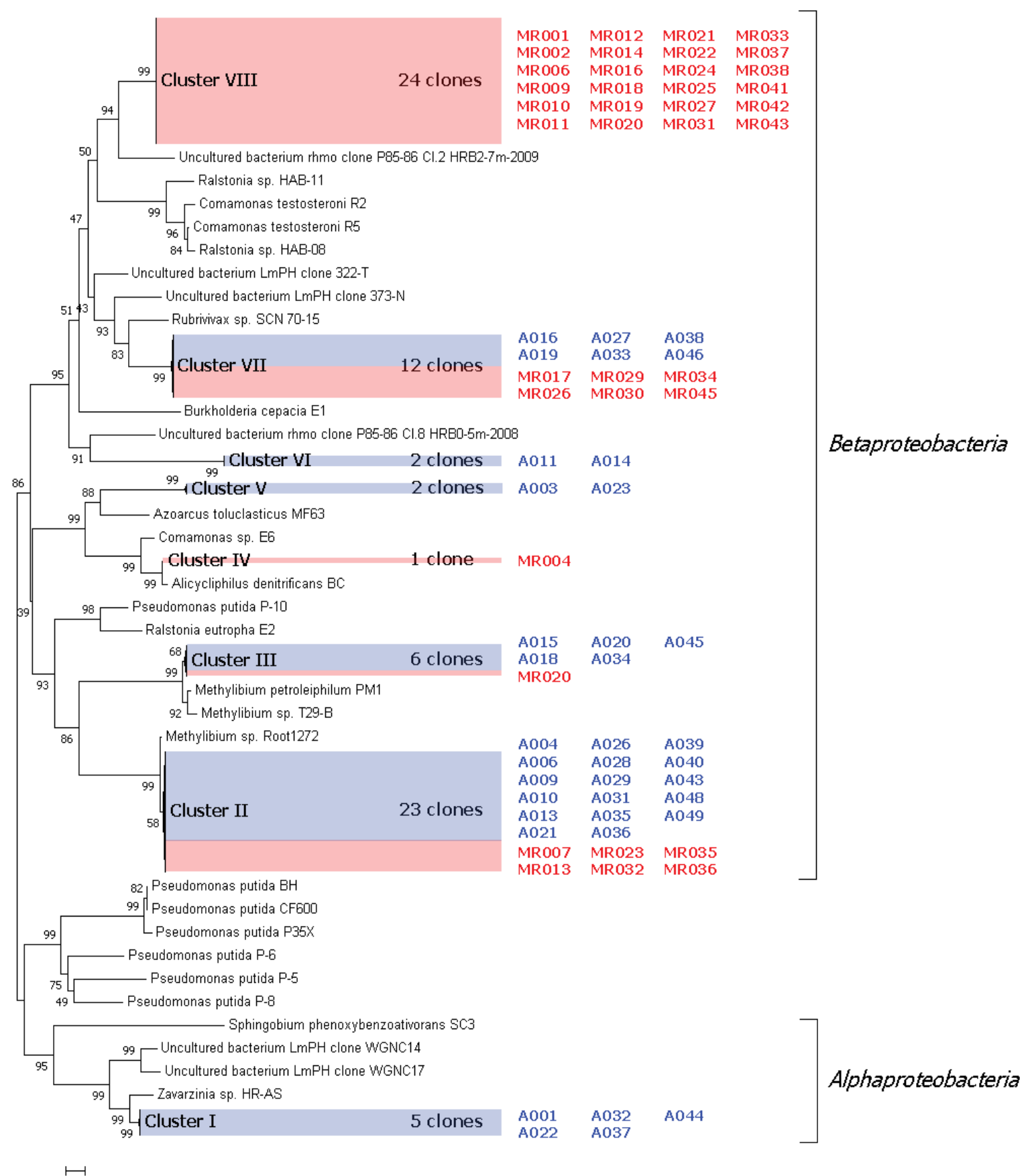

$\stackrel{5}{0.020}$

Figure 3. Phylogenetic relationship among partial phenol hydroxylase genes recovered from two wastewater processing tanks. Bootstrap analysis was conducted in 100 repeats. Horizontal bars indicate distance. Clusters highlighted in blue and red indicate the presence of clones generated from the aeration (A) and microbial recycle (MR) tanks, respectively. Clone names are represented on the right in respective colors. The height of the highlighted areas is relative to the number of clones represented.

Correspondingly, all cloned fragments were closely related to phenol hydroxylase-encoding genes belonging to bacteria with various lifestyles. This indicates that the microbes in wastewater sludge are indeed diverse in the sense of their biodegradation and metabolic roles. Our results showed that the microbial communities in the aeration and microbial recycle tanks were different, in which one cluster was exclusively found in each tank. This may be due to changes in the microenvironment conditions and a variety in toxicity tolerance of different strains of bacteria.

This study provides insight into the diversity of bacteria that may be involved in phenol decontamination, and this information should be considered in designing and improving the phenol-containing wastewater treatment system. This may be achieved by adjusting the waste 
processing conditions to promote the growth of prominent phenol degraders. Ultimately, the high-throughput investigation that will allow for wider coverage of the bacterial community, such as next-generation sequencing, may give more insight into potential novel bacteria with phenol-degrading capability.

\section{ACKNOWLEDGEMENTS}

This study is supported by the annual research gran from the Faculty of Biotechnology, Atma Jaya Catholic University of Indonesia.

\section{REFERENCES}

Aker AM, Ferguson KK, Rosario ZY, Mukherjee B, Alshawabkeh AN, Calafat AM, Cordero JF, Meeker JD. 2019. A repeated measures study of phenol, paraben and Triclocarban urinary biomarkers and circulating maternal hormones during gestation in the Puerto Rico PROTECT cohort. Environ Health 18 (1): 28. DOI: 10.1186/s12940019-0459-5

Barik M, Das CP, Verma AK, Sahoo S, Sahoo NK. 2021. Metabolic profiling of phenol biodegradation by an indigenous Rhodococcus pyridinivorans strain PDB9T $\mathrm{N}-1$ isolated from paper pulp wastewater. Int Biodeter Biodegrad 158: 105168. DOI: 10.1016/j.ibiod.2020.105168

Bera S, Roy AS, Mohanty K. 2017. Biodegradation of phenol by a native mixed bacterial culture isolated from crude oil contaminated site. Int Biodeter Biodegrad 121: 107-13. DOI: 10.1016/j.ibiod.2017.04.002

Chen KF, Chang YC, Huang SC. 2012. Biodegradation potential of MTBE and BTEX under aerobic, nitrate reducing, and methanogenic conditions at a gasoline-contaminated site. Desalin Water Treat 48 (13): 278-284. DOI: 10.1080/19443994.2012.698825

Chen R, Ren LF, Shao J, He Y, Zhang X. 2017. Changes in degrading ability, populations and metabolism of microbes in activated sludge in the treatment of phenol wastewater. RSC Adv 7 (83):5 2841-2851. DOI: 10.1039/C7RA09225C

Chenprakhon P, Pimviriyakul P, Tongsook C, Chaiyen P. 2020 Phenolic hydroxylases. In: The Enzymes 47: 283-326. Academic Press. DOI: 10.1016/bs.enz.2020.05.008

Futamata H, Harayama S, Watanabe K. 2001. Group-specific monitoring of phenol hydroxylase genes for a functional assessment of phenolstimulated trichloroethylene bioremediation. Appl Environ Microbiol 67: 4671-4677. DOI: 10.1128/AEM.67.10.4671-4677.2001

Harzallah B, Bousseboua H, Jouanneau Y. 2017. Diversity shift in bacterial phenol hydroxylases driven by alkyl-phenols in oil refinery wastewaters. Environ Sci Poll Res 24 (16): 14376-1486. DOI: 10.1007/s11356-017-8950-4

Hussain A, Dubey SK, Kumar V. 2015. Kinetic study for aerobic treatment of phenolic wastewater. Water Resour Ind 11: 81-90. DOI 10.1016/j.wri.2015.05.002

Kane SR, Chakicherla AY, Chain PSG, Schmidt R, Shin MW, Legler TC, Scow KM, Larimer FW, Lucas SM, Richardson PM, Hristova KR. 2007. Whole-genome analysis of the methyl tert-butyl etherdegrading beta-proteobacterium Methylibium petroleiphilum PM1. J Bacteriol 189: 1931-1945. DOI: 10.1128/JB.01259-06

Ke Q, Zhang Y, Wu X, Su X, Wang Y, Lin H, Mei R, Zhang Y, Hashmi MZ, Chen C, Chen J. 2018. Sustainable biodegradation of phenol by immobilized Bacillus sp. SAS19 with porous carbonaceous gels as carriers. J Environ Manag 222: 185-189. DOI: 10.1016/j.jenvman.2018.05.061

Kumar S, Stecher G, Tamura K. 2016. MEGA7: Molecular evolutionary genetics analysis version 7.0 for bigger datasets. Mol Biol Evol 33: 1870-1874. DOI: $10.1093 / \mathrm{molbev} / \mathrm{msw} 054$

Lee Y, Park HY, Jeon CO. 2019. Zavarzinia aquatilis sp. nov., isolated from a freshwater river. Int J Sys Evol Microbiol 69 (3): 727-731. DOI: 10.1099/ijsem.0.003214
Linder JU. 2015. The YHS-Domain of an adenylyl cyclase from Mycobacterium phlei is a probable copper-sensor module. PLoS One 10: e0141843. DOI: 10.1371/journal.pone.0141843

Mekala LP, Mohammed M, Chintalapati S, Chintalapati VR. 2018. Stable isotope-assisted metabolic profiling reveals growth mode dependent differential metabolism and multiple catabolic pathways of 1phenylalanine in Rubrivivax benzoatilyticus JA2. J Prot Res 17 (1): 189-202. DOI: 10.1021/acs.jproteome.7b00500

Michałowicz J, Włuka A, Cyrkler M, Maćczak A, Sicińska P, Mokra K. 2018. Phenol and chlorinated phenols exhibit different apoptotic potential in human red blood cells (in vitro study). Environ Toxicol Pharmacol 61: 95-101. DOI: 10.1016/j.etap.2018.05.014

Mohammed M, Mekala LP, Chintalapati S, Chintalapati VR. 2020. New insights into aniline toxicity: Aniline exposure triggers envelope stress and extracellular polymeric substance formation in Rubrivivax benzoatilyticus JA2. J Hazard Mat 385: 121571. DOI: 10.1016/j.jhazmat.2019.121571

Nagashima S, Kamimura A, Shimizu T, Nakamura-Isaki S, Aono E, Sakamoto K, Ichikawa N, Nakazawa H, Sekine M, Yamazaki S, Fujita N, Shimada K, Hanada S, Nagashima KVP. 2012. Complete genome sequence of phototrophic Betaproteobacterium Rubrivivax gelatinosus IL 144. J Bacteriol 194 (13): 3541-3542. DOI: 10.1128/JB.00511-12

Naguib DM, Badawy NM. 2020. Phenol removal from wastewater using waste products. J Environ Chem Eng 8 (1): 103592. DOI: 10.1016/j.jece.2019.103592

Nešvera J, Rucká L, Pátek M. 2015. Catabolism of phenol and its derivatives in bacteria: Genes, their regulation, and use in the biodegradation of toxic pollutants. Adv Appl Microbiol 93: 107-160. DOI: 10.1016/bs.aambs.2015.06.002

Oosterkamp MJ, Veuskens T, Talarico Saia F, Weelink SA, Goodwin LA, Daligault HE, Bruce DC, Detter JC, Tapia R, Han CS, Land ML. 2013. Genome analysis and physiological comparison of Alicycliphilus denitrificans strains BC and K601T. PLoS One 8 (6): e66971. DOI: 10.1371/journal.pone.0066971

Panigrahy N, Barik M, Sahoo NK. 2020. Kinetics of phenol biodegradation by an indigenous Pseudomonas citronellolis NS1 isolated from coke oven wastewater. J Hazard Toxic Rad Waste 24 (3): 04020019. DOI: 10.3390/plants10010118

Petkevičius V, Vaitekūnas J, Gasparavičiūtė R, Tauraitė D, Meškys R. 2021. An efficient and regioselective biocatalytic synthesis of aromatic $\mathrm{N}$-oxides by using a soluble di-iron monooxygenase PmlABCDEF produced in the Pseudomonas species. Microb Biotechnol 14 (4): 1771-1783. DOI: 10.1111/1751-7915.13849

Rochman FF, Sheremet A, Tamas I, Saidi-Mehrabad A, Kim J-J, Dong X, Sensen CW, Gieg LM, Dunfield PF. 2017. Benzene and naphthalene degrading bacterial communities in an oil sands tailings pond. Front Microbiol 8: 1845. DOI: 10.3389/fmicb.2017.01845

Sam SP, Tan HT, Sudesh K, Adnan R, Ting AS, Ng SL. 2021. Phenol and p-nitrophenol biodegradations by acclimated activated sludge: Influence of operational conditions on biodegradation kinetics and responding microbial communities. J Environ Chem Eng 9 (4): 105420. DOI: $10.1016 /$ j.jece.2021.105420

Setlhare B, Kumar A, Mokoena MP, Pillay B, Olaniran AO. 2020. Phenol hydroxylase from Pseudomonas sp. KZNSA: Purification, characterization and prediction of three-dimensional structure. Int $\mathbf{J}$ Biol Macromol 146: 1000-1008. DOI: 10.1016/j.ijbiomac.2019.09.224

Shannon CE, Weaver W. 1963. A Mathematical Theory of Communication. University of Illinois, Urbana-Champaign (USA). DOI: 10.1002/j.1538-7305.1948.tb01338.x

Sheu SY, Li ZH, Young CC, Chen WM. 2020. Rubrivivax albus sp. nov., isolated from a freshwater pond. Int J Syst Evol Microbiol 70 (2): 805-813. DOI: 10.1099/ijsem.0.003829

Silva CC, Hayden H, Sawbridge T, Mele P, De Paula SO, Silva LC, Vidigal PM, Vicentini R, Sousa MP, Torres AP, Santiago VM. 2013. Identification of genes and pathways related to phenol degradation in metagenomic libraries from petroleum refinery wastewater. PLoS One 8 (4): e61811. DOI: 10.1371/journal.pone.0061811

Silva CC, Hayden H, Sawbridge T, Mele P, Kruger RH, Rodrigues MV, Costa GG, Vidal RO, Sousa MP, Torres AP, Santiago VM. 2012. Phylogenetic and functional diversity of metagenomic libraries of phenol degrading sludge from petroleum refinery wastewater treatment system. AMB Express 2: 18. DOI: 10.1186/2191-0855-2-18

Song B, Haggblom MM, Zhou J, Tiedje JM, Palleroni NJ. 1999. Taxonomic characterization of denitrifying bacteria that degrade 
aromatic compounds and description of Azoarcus toluvorans sp. nov. and Azoarcus toluclasticus sp. nov. Int J Syst Bacteriol 49: 11291140. DOI: $10.1099 / 00207713-49-3-1129$

Stefanakis AI. 2020. The fate of MTBE and BTEX in constructed wetlands. Appl Sci 10 (1): 127. DOI: 10.3390/app10010127

Tan WA, Parales RE. 2019. Hydrocarbon degradation by betaproteobacteria. In: McGenity TJ, editor. Taxonomy, Genomics and Ecophysiology of Hydrocarbon-Degrading Microbes. Springer Berlin Heidelberg, Berlin. DOI: 10.1007/978-3-540-77587-4

Viggor S, Jõesaar M, Soares-Castro P, Ilmjärv T, Santos PM, Kapley A, Kivisaar M. 2020. Microbial metabolic potential of phenol degradation in wastewater treatment plant of crude oil refinery:
Analysis of metagenomes and characterization of isolates. Microorganisms 8 (5): 652. DOI: 10.3390/microorganisms8050652

Weelink SAB, Tan NCG, Ten Broeke H, Van Den Kieboom C, Van Doesburg W, Langenhoff AAM, Gerritse J, Junca H, Stams AJM. 2008. Isolation and characterization of Alicycliphilus denitrificans strain BC, which grows on benzene with chlorate as the electron acceptor. Appl Environ Microbiol 74: 6672-6681. DOI: 10.1128/AEM.00835-08

Zhong W, Wang D, Xu X. 2012. Phenol removal efficiencies of sewage treatment processes and ecological risks associated with phenols in effluents. J Hazard Mat 217: 286-292. DOI: 10.1016/j.jhazmat.2012.03.026 